\title{
ERRATUM
}

\section{UM-Chor1: establishment and characterization of the first validated clival chordoma cell line}

TO THE READERSHIP: An error appeared in the article by Owen et al. (Owen JH, Komarck CM, Wang AC, et al: UM-Chorl: establishment and characterization of the first validated clival chordoma cell line. J Neurosurg [epub ahead of print April 21, 2017; DOI: 10.3171/2016.10. JNS16877]).

The Acknowledgments section was incomplete. The updated information appears below.

We would like to acknowledge continued guidance and support from the Chordoma Foundation and the assistance of the University of Michigan Flow Cytometry Core and the University of Michigan Vector Core. Funding was provided by National Research Service Award Grant 1F32NS074744-01 and by the National Institutes of Health through Grants R01CA148621 (X.F.) and R01CA163737 (X.F.). We also would like to acknowledge grant support to Dr. Fan from Accelerate Brain Cancer Cure Project Award, American Brain Tumor Association Translational Grant, and Voices Against Brain Cancer Research Grant. 2017.

The article has been corrected online as of May 19,

Mark E. P. Prince, MD

Xing Fan, MD, PhD

University of Michigan, Ann Arbor, MI

CORRESPONDING ARTICLE See pp 701-709.

INCLUDE WHEN CITING

Published online May 19, 2017; DOI: 10.3171/2017.4.JNS16877a.

CAANS 2018, except where prohibited by US copyright law 